\title{
Electrocatalytic $\mathrm{CO}_{2}$ Reduction to Ethylene over $\mathrm{CeO}_{2}$-Supported $\mathrm{Cu}$ Nanoparticles: Effect of Exposed Facets of $\mathrm{CeO}_{2}$
}

\author{
Senlin Chu ${ }^{1}$, Xin Li ${ }^{1}$, Alex W. Robertson ${ }^{2}$, Zhenyu Sun ${ }^{1, *}$ \\ ${ }^{1}$ State Key Laboratory of Organic-Inorganic Composites, College of Chemical Engineering, Beijing University of Chemical \\ Technology, Beijing 100029, China. \\ ${ }^{2}$ Department of Materials, University of Oxford, Oxford, OX1 3PH, UK.
}

\begin{abstract}
Fossil fuels are expected to be the major source of energy for the next few decades. However, combustion of nonrenewable resources leads to the release of large quantities of $\mathrm{CO}_{2}$, the primary greenhouse gas. Notably, the concentration of $\mathrm{CO}_{2}$ in the atmosphere is increasing annually at an astounding rate. Electrochemical $\mathrm{CO}_{2}$ reduction (ECR) to value-added fuels and chemicals using electricity from intermittent renewable energy sources is a carbon-neutral method to alleviate anthropogenic $\mathrm{CO}_{2}$ emissions. Despite the steady progress in the selective generation of $\mathrm{C}_{1}$ products ( $\mathrm{CO}$ and formic acid), the production of multi-carbon species still suffers from low selectivity and efficiency. As an ECR product, ethylene $\left(\mathrm{C}_{2} \mathrm{H}_{4}\right)$ has a higher energy density than do $\mathrm{C}_{1}$ species and is an important industrial feedstock in high demand. However, the conversion of $\mathrm{CO}_{2}$ to $\mathrm{C}_{2} \mathrm{H}_{4}$ is plagued by low productivity and large overpotential, in addition to the severe competing hydrogen evolution reaction (HER) during the ECR. To address these issues, the

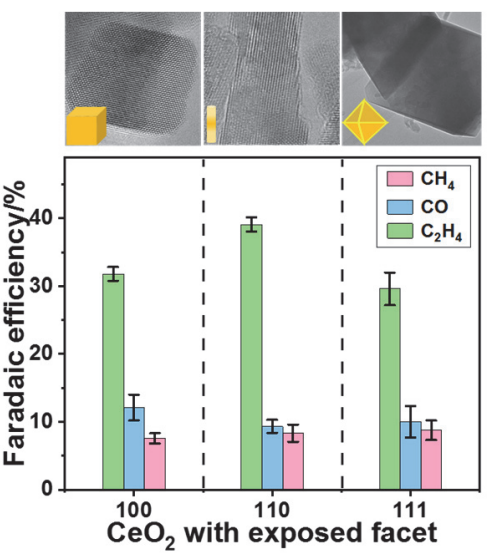
design and development of advanced electrocatalysts are critical. Here, we demonstrate fine-tuning of $\mathrm{ECR}$ to $\mathrm{C}_{2} \mathrm{H}_{4}$ by taking advantage of the prominent interaction of $\mathrm{Cu}$ with shape-controlled $\mathrm{CeO}_{2}$ nanocrystals, that is, cubes, rods, and octahedra predominantly covered with (100), (110), and (111) surfaces, respectively. We found that the selectivity and activity of the ECR depended strongly on the exposed crystal facets of $\mathrm{CeO}_{2}$. The overall ECR Faradaic efficiency (FE) over $\mathrm{Cu} / \mathrm{CeO}_{2}(110)(\mathrm{FE} \approx 56.7 \%)$ surpassed that of both $\mathrm{Cu} / \mathrm{CeO}_{2}(100)(\mathrm{FE} \approx 51.5 \%)$ and $\mathrm{Cu} / \mathrm{CeO} 2(111)(\mathrm{FE} \approx$ $48.4 \%$ ) in $0.1 \mathrm{~mol} \cdot \mathrm{L}^{-1} \mathrm{KHCO}_{3}$ solutions with an $\mathrm{H}$-type cell. This was in stark contrast to the exclusive occurrence of the HER over pure carbon paper, $\mathrm{CeO}_{2}(100), \mathrm{CeO}_{2}(110)$, and $\mathrm{CeO}_{2}(111)$. In particular, the $\mathrm{FE}$ toward $\mathrm{C}_{2} \mathrm{H}_{4}$ formation and the partial current density increased in the sequence $\mathrm{Cu} / \mathrm{CeO}_{2}(111)<\mathrm{Cu} / \mathrm{CeO}_{2}(100)<\mathrm{Cu} / \mathrm{CeO}_{2}(110)$ within applied bias potentials from -1.00 to $-1.15 \mathrm{~V}$ (vs. the reversible hydrogen electrode), reaching $39.1 \%$ over $\mathrm{Cu} / \mathrm{CeO}_{2}(110)$ at a mild overpotential $(1.13 \mathrm{~V})$. The corresponding values for $\mathrm{Cu} / \mathrm{CeO}_{2}(100)$ and $\mathrm{Cu} / \mathrm{CeO}_{2}(111)$ were $\mathrm{FE}_{\mathrm{C}_{2} \mathrm{H}_{4}} \approx 31.8 \%$ and $\mathrm{FE}_{\mathrm{C}_{2} \mathrm{H}_{4} \approx} \approx$ $29.6 \%$, respectively. The $\mathrm{C}_{2} \mathrm{H}_{4}$ selectivity was comparable to that of many reported Cu-based electrocatalysts at similar overpotentials. Furthermore, the $\mathrm{FE}$ for $\mathrm{C}_{2} \mathrm{H}_{4}$ remained stable even after $6 \mathrm{~h}$ of continuous electrolysis. The superior ECR activity of $\mathrm{Cu} / \mathrm{CeO}_{2}(110)$ to yield $\mathrm{C}_{2} \mathrm{H}_{4}$ was attributed to the metastable (110) surface, which not only promoted the effective adsorption of $\mathrm{CO}_{2}$ but also remarkably stabilized $\mathrm{Cu}^{+}$, thereby boosting the $\mathrm{ECR}$ to produce $\mathrm{C}_{2} \mathrm{H}_{4}$. This work offers an alternative strategy to enhance the ECR efficiency by crystal facet engineering.
\end{abstract}

Key Words: $\mathrm{CO}_{2} ; \quad$ Electrochemical reduction; Ethylene; $\mathrm{Cu} ; \mathrm{CeO}_{2} ; \quad$ Exposed facet 


\title{
$\mathrm{CeO}_{2}$ 担载 $\mathrm{Cu}$ 纳米粒子电催化 $\mathrm{CO}_{2}$ 还原产乙烯: $\mathrm{CeO}_{2}$ 不同暴露晶 面对催化性能的影响
}

\author{
楚森林 ${ }^{1}$, 李欣 ${ }^{1}$, Alex W. Robertson ${ }^{2}$, 孙振宇 1 , ${ }^{*}$ \\ 1 北京化工大学化学工程学院, 有机-无机复合材料国家重点实验室, 北京 100029 \\ 2 牛津大学材料系, 牛津 $\mathrm{OX} 13 \mathrm{PH}$
}

\begin{abstract}
摘要: 化石燃料在未来几十年仍然是主要的能量来源, 但是这种不可再生资源的燃烧释放出大量的 $\mathrm{CO}_{2}$ (主要的温室气 体), 空气中 $\mathrm{CO}_{2}$ 的浓度每年仍然持续增加。使用间歇性可再生能源转化的电能驱动电化学 $\mathrm{CO}_{2}$ 还原生成高附加值产品为 其减排提供了一种有前景、 $\mathrm{CO}_{2}$ “零排放” 的方法。本文通过利用 $\mathrm{Cu}$ 和不同形状的 $\mathrm{CeO}_{2}$ 纳米晶之间的相互作用, 即分别 暴露(100)、(110)、(111)晶面的立方体、棒状和八面体 $\mathrm{CeO}_{2}$, 实现了对电化学 $\mathrm{CO}_{2}$ 还原产乙烯的有效调控。研究发现, 电化学 $\mathrm{CO}_{2}$ 还原的选择性和活性与 $\mathrm{CeO}_{2}$ 暴露的晶面密切相关, 生成乙烯的法拉第效率和偏电流密度在 1.00 到1.15 V (相 对于可逆氢电极)的施加电势范围内呈现出 $\mathrm{Cu} / \mathrm{CeO}_{2}(111)<\mathrm{Cu} / \mathrm{CeO}_{2}(100)<\mathrm{Cu} / \mathrm{CeO}_{2}(110)$ 的趋势。在H-型电解池中, 以 $0.1 \mathrm{~mol} \cdot \mathrm{L}^{-1} \mathrm{KHCO}_{3}$ 溶液为电解质, $\mathrm{Cu} / \mathrm{CeO}_{2}(110)$ 电催化 $\mathrm{CO}_{2}$ 还原的法拉第效率为 $56.7 \%$, 这与纯碳纸、 $\mathrm{CeO}_{2}(100)$ 、 $\mathrm{CeO}_{2}(110) 、 \mathrm{CeO}_{2}$ (111) 纳米颗粒上只发生析氢副反应形成了鲜明对比, 并且 $\mathrm{Cu} / \mathrm{CeO}_{2}$ (110)可在较温和的过电势下(1.13 V)电催化 $\mathrm{CO}_{2}$ 还原产乙烯, 其法拉第效率达到 $39.1 \%$, 和文献报道的很多 $\mathrm{Cu}$-基材料的性能相当, 而 $\mathrm{Cu} / \mathrm{CeO}_{2}(100)$ 与 $\mathrm{Cu} / \mathrm{CeO}_{2}(111)$ 产乙烯的法拉第效率分别为 $31.8 \%$ 和 $29.6 \%$ 。此外, 经过 $6 \mathrm{~h}$ 的持续电解后, 乙烯的法拉第效率基本保持稳 定。 $\mathrm{Cu} / \mathrm{CeO}_{2}(110)$ 还原 $\mathrm{CO}_{2}$ 产乙烯的活性可能与 $\mathrm{CeO}_{2}(110)$ 表面的亚稳态性质有关, 其不仅能有效促进 $\mathrm{CO}_{2}$ 的吸附, 还 能有效稳定 $\mathrm{Cu}^{+}$, 从而促进了 $\mathrm{CO}_{2}$ 还原为乙烯。本工作为增强电化学 $\mathrm{CO}_{2}$ 还原提供了晶面工程途径。
\end{abstract}

关键词: 二氧化碳; 电化学还原; 乙烯; 铜; 二氧化铈；暴露晶面 中图分类号: 0646

\section{Introduction}

Anthropogenic global warming is a dire consequence of excess emissions of greenhouse gases, mostly carbon dioxide $\left(\mathrm{CO}_{2}\right)^{1-3}$. The steady increase in the concentration of atmospheric $\mathrm{CO}_{2}$, from $270 \times 10^{-6}$ in the preindustrial era to more than $407 \times 10^{-6}$ by 2019 , and probably approaching $600 \times$ $10^{-6}$ by 2100 , intensifies such catastrophic effect. Electrochemical $\mathrm{CO}_{2}$ reduction (ECR) powered by renewably generated electricity offers a mild and clean way to mitigate this issue $^{4-10}$. ECR also offers an avenue to resolving energy security and energy sustainability. ECR can proceed via multiple concerted proton-electron transfer processes. Based on the number of electrons and protons transferred, $\mathrm{CO}_{2}$ can be converted to different products. However, $\mathrm{CO}_{2}$ has remarkable thermodynamic stability and requires high energy to be activated. Efficient conversion of $\mathrm{CO}_{2}$ is only achievable through the design of advanced electrocatalysts with optimized structures ${ }^{11-14}$.

ECR to $\mathrm{C}_{1}$ species such as carbon monoxide (CO) ${ }^{15-17}$ and formic acid $(\mathrm{HCOOH}){ }^{18}$ has been achieved at a very high Faradaic efficiency (FE) exceeding 90\%, while production of multi-carbon compounds remains a grand challenge ${ }^{19}$. Among the reported electrocatalysts, $\mathrm{Cu}$ appears to be the only metal that is capable of catalyzing the ECR to not only $\mathrm{HCOOH}$ and $\mathrm{CO}$ but also a range of hydrocarbons and oxygenates (aldehydes, and alcohols) ${ }^{12} \cdot \mathrm{Cu}$ possesses a suitable binding strength of $* \mathrm{CO}$ (affinity not too weak and not too strong) to obey the Sabatier principle, favoring further $\mathrm{C}-\mathrm{C}$ coupling transformation. Also, it has a negative adsorption energy for $\mathrm{CO}^{*}$ but a positive adsorption energy for $\mathrm{H}^{*}$ (an intermediate formed in the hydrogen evolution reaction, HER) ${ }^{20} \cdot \mathrm{C}_{2} \mathrm{H}_{4}$ is a widely used feedstock for producing plastics, ethylene oxide, and diesel fuels. However, due to the concurrent generation of $\mathrm{H}_{2}$ and other $\mathrm{C}_{1}$ compounds, the $\mathrm{FE}$ for the production of $\mathrm{C}_{2} \mathrm{H}_{4}\left(\mathrm{FE}_{\left.\mathrm{C}_{2} \mathrm{H}_{4}\right)}\right)$ on metallic $\mathrm{Cu}$ is low. Efforts to improve the $\mathrm{FE}_{\mathrm{C}_{2} \mathrm{H}_{4}}$ have been made on optimizing the sizes, morphologies, and exposed crystal lattices of metallic $\mathrm{Cu}$ nanoparticles (NPs) ${ }^{21-23}$. In addition, $\mathrm{Cu}$ /oxide interfaces are considered to play a role in impeding the undesired HER during ECR. In our previous work, we found that tuning the composition and interface of $\mathrm{CuO}$ and $\mathrm{Sb}_{2} \mathrm{O}_{3}$ or $\mathrm{In}_{2} \mathrm{O}_{3}$ enabled substantially enhanced $\mathrm{CO}_{2}$-to- $\mathrm{CO}$ conversion ${ }^{24,25}$. The $\mathrm{CO} \mathrm{FE}$ was as high as $93.0 \%$ over $\mathrm{CuO}-\mathrm{In}_{2} \mathrm{O}_{3}$ composite catalysts ${ }^{26} . \mathrm{CeO}_{2}$ has been regarded as a remarkable catalyst or support owing to its redox behavior and oxygen storage capacity ${ }^{27-34}$. Of particular interest, $\mathrm{CeO}_{2}$ was found to effectively stabilize $\mathrm{Cu}^{+}$, thereby boosting the ECR selectively to yield $\mathrm{C}_{2} \mathrm{H}_{4}$ over $\mathrm{CuO}^{35}$. Despite these advances, effects of the interaction between metallic $\mathrm{Cu}$ and $\mathrm{CeO}_{2}$ with varying exposed facets on ECR have not been explored thus far.

Herein, we investigated the ECR performance of $\mathrm{Cu}$ NPs supported on different shaped-controlled $\mathrm{CeO}_{2}$ nanocrystals. The ECR selectivity and activity was found to be significantly 
affected by the exposed crystal facets of $\mathrm{CeO}_{2}$. Furthermore, the $\mathrm{FE}_{\mathrm{C}_{2} \mathrm{H}_{4}}$ was shown to increase following the trend of $\mathrm{Cu} / \mathrm{CeO}_{2}(111)<\mathrm{Cu} / \mathrm{CeO}_{2}(100)<\mathrm{Cu} / \mathrm{CeO}_{2}(110)$. We found that $\mathrm{CeO}_{2}$ changed the oxidation state of $\mathrm{Cu}$ atoms toward $\mathrm{Cu}^{+}$at the $\mathrm{CuO}-\mathrm{CeO}_{2}$ interface with $\mathrm{CeO}_{2}(110)$ being more remarkably than $\mathrm{CeO}_{2}(100)$ and $\mathrm{CeO}_{2}(111)$. The existence of $\mathrm{Cu}^{+}$species was supposed to be likely the adsorption and active sites for $\mathrm{CO}_{2}$ activation followed by further $\mathrm{C}-\mathrm{C}$ coupling to yield $\mathrm{C}_{2} \mathrm{H}_{4}$.

\section{Experimental}

\subsection{Materials}

$\mathrm{Ce}\left(\mathrm{NO}_{3}\right)_{3} \cdot 6 \mathrm{H}_{2} \mathrm{O}$ (Product number: C105376, 99.5\%), $\mathrm{Na}_{3} \mathrm{PO}_{4} \cdot 12 \mathrm{H}_{2} \mathrm{O}$ (Product number: $\mathrm{S} 112445$, 98.0\%), $\mathrm{Cu}(\mathrm{Ac})_{2} \cdot \mathrm{H}_{2} \mathrm{O}$ (Product number: $\mathrm{C} 108085,99.95 \%$ ), $\mathrm{NaBH}_{4}$ (Product number: S108355, 98.0\%) and ethanol (Product number: E111963, 99.9\%) were purchased from Aladdin (Shanghai, China). NaOH (Product number: S817970, 97.0\%) was provided by Maclin (Shanghai, China). All raw materials were used as received without additional treatments.

\subsection{Synthesis of $\mathrm{CeO}_{2}$ cubes, rods, and octahedra predominantly covered with (100), (110), and (111) surfaces, respectively}

$\mathrm{CeO}_{2}$ cubes were synthesized using a hydrothermal method ${ }^{36}$. Typically, $9.6 \mathrm{~g}$ of $\mathrm{NaOH}$ and $40.0 \mathrm{~mL}$ of deionized (DI) water were added in a Teflon-lined steel reactor $(100 \mathrm{~mL})$ and mixed with $0.868 \mathrm{~g}$ of $\mathrm{Ce}\left(\mathrm{NO}_{3}\right)_{3} \cdot 6 \mathrm{H}_{2} \mathrm{O}$ under magnetic stirring for 30 min to yield a white suspension. The reactor was sealed and heated at $453 \mathrm{~K}$ for $24 \mathrm{~h}$. The resulting precipitate was separated by centrifugation and washed with excess DI water and ethanol four times, followed by drying at $353 \mathrm{~K}$ for $8 \mathrm{~h}$. The obtained powder was then treated at $673 \mathrm{~K}$ for $4 \mathrm{~h}$ at a heating rate of 5 $\mathrm{K} \cdot \mathrm{min}^{-1}$.

$\mathrm{CeO}_{2}$ nanorods were prepared by adapting a similar hydrothermal method ${ }^{37}$. Specifically, $8.44 \mathrm{~g}$ of $\mathrm{NaOH}$ and 15.0 $\mathrm{mL}$ of DI water were added in a Teflon-lined steel reactor $(100$ $\mathrm{mL}$ ) and mixed with $0.88 \mathrm{~g}$ of $\mathrm{Ce}\left(\mathrm{NO}_{3}\right)_{3} \cdot 6 \mathrm{H}_{2} \mathrm{O}$ and $20.0 \mathrm{~mL}$ of DI water under magnetic stirring for $30 \mathrm{~min}$ to form a white slurry. The reactor was sealed and heated at $453 \mathrm{~K}$ for $24 \mathrm{~h}$. The resulting precipitate was separated by centrifugation and washed with a mixture of excess DI water and ethanol four times, and subsequently dried at $333 \mathrm{~K}$ for $6 \mathrm{~h}$. The obtained powder was subsequently treated at $773 \mathrm{~K}$ for $4 \mathrm{~h}$ under $\mathrm{Ar}$ at a heating rate of $5 \mathrm{~K} \cdot \mathrm{min}^{-1}$.

$\mathrm{CeO}_{2}$ octahedra were produced using a modified hydrothermal method ${ }^{36} \cdot 0.0038 \mathrm{~g}$ of $\mathrm{Na}_{3} \mathrm{PO}_{4} \cdot 12 \mathrm{H}_{2} \mathrm{O}$ and 40.0 $\mathrm{mL}$ of DI water were loaded in a Teflon-lined steel reactor (100 $\mathrm{mL}$ ), followed by mixing with $0.434 \mathrm{~g}$ of $\mathrm{Ce}\left(\mathrm{NO}_{3}\right)_{3} \cdot 6 \mathrm{H}_{2} \mathrm{O}$ under vigorous magnetic stirring for $30 \mathrm{~min}$. The reactor was sealed and heated at $473 \mathrm{~K}$ for $20 \mathrm{~h}$. The resulting precipitates were separated by centrifugation and washed with excess DI water and ethanol four times, followed by drying at $353 \mathrm{~K}$ for $8 \mathrm{~h}$. The obtained powder was then calcined at $673 \mathrm{~K}$ for $4 \mathrm{~h}$ at a heating rate of $5 \mathrm{~K} \cdot \mathrm{min}^{-1}$.

\subsection{Preparation of $\mathrm{Cu} / \mathrm{CeO}_{2}$ catalysts}

$\mathrm{Cu}$ nanoparticles were immobilized on the surface of $\mathrm{CeO}_{2}$ through an ultrasonication-facilitated deposition method using sodium borohydride as a reductant. Typically, $20.0 \mathrm{mg}$ of $\mathrm{CeO}_{2}$ powder with controlled shapes and a specific amount of $\mathrm{Cu}(\mathrm{Ac})_{2} \cdot \mathrm{H}_{2} \mathrm{O}$ were dissolved in $20.0 \mathrm{~mL}$ of ethanol. The resultant solution was subjected to ultrasonication for $10 \mathrm{~min}$ to ensure a complete mixing. $10.0 \mathrm{~mL}$ of $0.1 \mathrm{~mol} \cdot \mathrm{L}^{-1} \mathrm{NaBH}_{4}$ ethanol solution was added into the solution under nitrogen, which was ultrasonicated for another $20 \mathrm{~min}$. The resulting precipitate was separated by centrifugation and washed with a mixture of excess DI water and ethanol four times, and then dried in a vacuum oven at $273 \mathrm{~K}$ for $8 \mathrm{~h}$.

\subsection{Characterization}

X-ray powder diffraction (XRD) was carried out with a D/MAX-RC diffractometer (Japan) operated at $30 \mathrm{kV}$ and 100 $\mathrm{mA}$ with $\mathrm{Cu} K_{\alpha}$ radiation $(\lambda=0.15418 \mathrm{~nm})$. X-ray photoelectron spectroscopy (XPS) experiments were conducted using Thermo Scientific ESCALAB 250Xi instrument (UK) equipped with an electron flood and scanning ion gun. All spectra were calibrated to the $\mathrm{C} 1 s$ binding energy at $284.8 \mathrm{eV}$. High-angle annular darkfield scanning transmission electron microscopy (HAADFSTEM) was recorded using a JEOL ARM200 microscope (Japan) operated at $200 \mathrm{kV}$ voltage. High-resolution (HR) transmission electron microscopy (TEM) was performed using a JEOL 3000F (Japan). TEM and STEM samples were obtained by dropping a droplet of suspension onto a $\mathrm{Ni}$ grid coated with a lacey carbon film. The Brunauer-Emmett-Teller specific surface areas of samples were determined using a physical adsorption instrument (Micromeritics ASAP 2020, USA) at $77 \mathrm{~K}$. The sample was subjected to degassing at $120{ }^{\circ} \mathrm{C}$ for $12 \mathrm{~h}$.

\subsection{Electrochemical measurements}

Controlled potential electrolysis was performed in a conventional H-type cell reactor separated by a cationic polymeric membrane (Nafion 117). Prior to ECR measurements, the Nafion membrane was heated in $\mathrm{H}_{2} \mathrm{O}_{2}$ aqueous solution $(5.0 \%)$ and $\mathrm{H}_{2} \mathrm{SO}_{4}\left(0.5 \mathrm{~mol} \cdot \mathrm{L}^{-1}\right)$ at $80{ }^{\circ} \mathrm{C}$ for $1 \mathrm{~h}$, respectively. Subsequently, the Nafion membrane was soaked in DI water at room temperature and left for $30 \mathrm{~min}$ and then washed with DI water. $12.0 \mathrm{mg}$ of a catalyst was suspended in $2.4 \mathrm{~mL}$ of a mixture of isopropanol, DI, and Nafion solution $(5.0 \%$ ( $w$, mass fraction)) with a respective volume ratio of $100: 100: 1$ under ultrasonication for $30 \mathrm{~min}$ to yield a homogeneous dispersion. $240 \mu \mathrm{L}$ of the dispersion was then deposited onto a Toray Carbon fiber paper electrode $(1.2 \mathrm{~cm} \times 1 \mathrm{~cm})$, and dried under room temperature. A Pt wire and an $\mathrm{Ag} / \mathrm{AgCl}$ electrode were used as the counter electrode and reference electrode, respectively. The potentials were controlled by an electrochemical working station (CHI 760E, Shanghai CH Instruments Co., China). All voltages in this study were provided relative to the $\mathrm{Ag} / \mathrm{AgCl}$ reference electrode (in $\mathrm{KCl}$ solution, $3.5 \mathrm{~mol} \cdot \mathrm{L}^{-1}$ ) and converted to the RHE reference scale based on the equation

$E(v s \mathrm{RHE})=E(v s \mathrm{Ag} / \mathrm{AgCl})+0.197+0.0591 \times \mathrm{pH}$ 
ECR was conducted in $\mathrm{CO}_{2}$-saturated $0.1 \mathrm{~mol} \cdot \mathrm{L}^{-1} \mathrm{KHCO}_{3}$ ( $\mathrm{pH}$ 6.8) under ambient conditions. $\mathrm{CO}_{2}$ was bubbled in the $\mathrm{KHCO}_{3}$ electrolytes for $30 \mathrm{~min}$ to expel residual air in the solution, and controlled electrolysis was carried out at each potential for $60 \mathrm{~min}$.

Linear sweep voltammograms in $\mathrm{Ar}$ - or $\mathrm{CO}_{2}$ environment were obtained by using a three-electrode configuration with an $\mathrm{Ag} / \mathrm{AgCl}$ reference electrode, $\mathrm{Pt}$ wire counter electrode, and glassy carbon working electrode on a CHI 760E potentiostat. Rotating disk electrode (RDE) experiments were performed on an AFMSRCE RDE control system (Pine Inc., USA). The electrolyte is $0.1 \mathrm{~mol} \cdot \mathrm{L}^{-1} \mathrm{KHCO}_{3}$ solution bubbled with $\mathrm{Ar}$ or $\mathrm{CO}_{2}$ for $30 \mathrm{~min}$. To attain linear sweep voltammograms, $6 \mathrm{mg}$ of a catalyst was suspended in a solution containing ethanol $(600$ $\mu \mathrm{L})$, DI water $(600 \mu \mathrm{L})$, and Nafion solution $(1.0 \%(w), 600 \mu \mathrm{L})$. Then, the mixture was treated under ultrasonication for $30 \mathrm{~min}$ to yield an ink. $7.95 \mu \mathrm{L}$ of the ink was subsequently loaded onto a glassy carbon electrode and dried at room temperature.

\subsection{Quantitative determination of gaseous and liquid products}

The gas-phase products after ECR were analyzed by an Agilent 7890B gas chromatography (GC) with two thermal conductivity detectors (TCD) and one flame ionization detector (FID). To probe the gas products, $20 \mathrm{~mL}$ of produced gas in the dead volume of a gas bag ( $\sim 2 \mathrm{~L})$ was injected into the $\mathrm{GC}$ at equivalent conditions with a sample lock syringe. $\mathrm{CO}, \mathrm{C}_{2} \mathrm{H}_{4}$, $\mathrm{CH}_{4}$, and $\mathrm{H}_{2}$ mole fractions of injected samples could be determined based on GC calibration curves. The amounts of liquid products ( $n$ in moles) were measured using nuclear magnetic resonance (NMR, Bruker Avance III 400 HD spectrometer). NMR samples were made by blending $0.5 \mathrm{~mL}$ of the product-containing electrolyte and $0.1 \mathrm{~mL}$ of DMSO- $\mathrm{d}_{6}$ as the internal standard. The FE of a product was determined using the equation:

$\mathrm{FE}=Q_{\text {product }} / Q_{\text {total }}=(m F \times n) /(I \times t)$

Where $F$ represents the Faraday constant $\left(96485 \mathrm{C} \cdot \mathrm{mol}^{-1}\right), n$

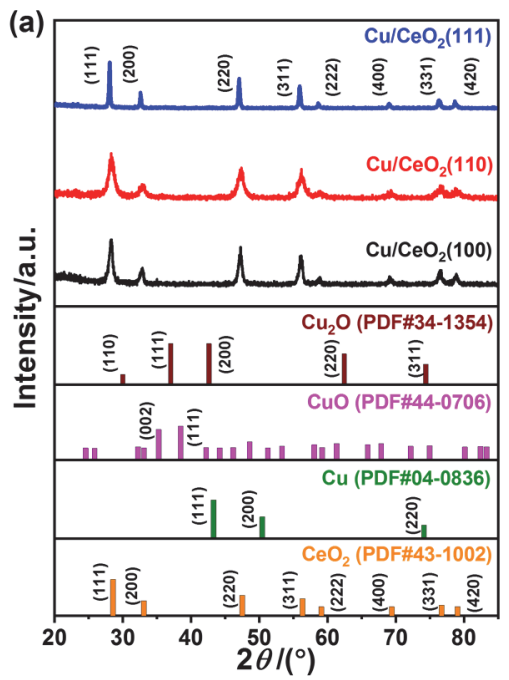

the number of moles for a product, $m$ (in number) the electrons needed for the formation of one product molecule. The amount of charge ( $Q$ in Coulomb) passed to generate products was determined. $I$ (in ampere) stands for the constant current at an applied potential. $t$ (in second) corresponds to the electrolysis time.

\section{Results and discussion}

\subsection{Morphology and structure analysis}

The X-ray diffraction (XRD) analysis results of the asobtained $\mathrm{Cu} / \mathrm{CeO}_{2}$ samples, along with the patterns of standard $\mathrm{CeO}_{2}$, metallic $\mathrm{Cu}$, and $\mathrm{CuO}_{x}$, are provided in Fig. 1a. The diffraction peaks appearing around $28.1^{\circ}, 32.5^{\circ}, 47.1^{\circ}, 55.9^{\circ}$, $58.6^{\circ}, 69.0^{\circ}, 76.2^{\circ}$, and $78.7^{\circ}$, could be well indexed to the (111), (200), (220), (311), (222), (400), (331), and (420) planes of $\mathrm{CeO}_{2}$ (PDF\#43-1002), respectively. This suggests the yield of fluorite $(F m 3 m) \mathrm{CeO}_{2}$ with a face-centered cubic $(f c c)$ structure in the composites ${ }^{38}$. No typical reflections of $\mathrm{Cu}, \mathrm{Cu}_{2} \mathrm{O}$, and $\mathrm{CuO}$ were observed in all cases, plausibly resulting from the low loading and/or small sizes of $\mathrm{Cu}$ in the samples.

To probe the surface composition and chemical state of $\mathrm{Cu}$ and $\mathrm{Ce}$, as well as their interactions, XPS was performed. The $\mathrm{Cu} 2 p$ XPS spectrum of $\mathrm{Cu} / \mathrm{CeO}_{2}(110)$ was provided in Fig. 1 b. Pronounced peaks of $\mathrm{Cu} 2 p_{1 / 2}$ with binding energies (BEs) at 952.3 and $954.2 \mathrm{eV}$ were clearly observed, generally associated with the $\mathrm{Cu}^{0} / \mathrm{Cu}^{+}$and $\mathrm{Cu}^{2+}$ species, respectively ${ }^{35}$. Three satellite peaks at about 940.9, 943.6, and $962.5 \mathrm{eV}$ (Figs. 1b and $\mathrm{S} 1 \mathrm{a}$ and $\mathrm{S} 1 \mathrm{~b}$ ) originated from $\mathrm{Cu}^{2+}$, while a satellite peak at about $571.2 \mathrm{eV}$ (Fig. S1c-e) corresponded to $\mathrm{Cu}^{+}{ }^{39}$. The existence of oxidized $\mathrm{Cu}$ is probably due to oxidation of the sample after exposure in the air. Interestingly, the content of $\mathrm{Cu}^{+}$ was found to follow the sequence of $\mathrm{Cu} / \mathrm{CeO}_{2}(110)>$ $\mathrm{Cu} / \mathrm{CeO}_{2}(100)>\mathrm{Cu} / \mathrm{CeO}_{2}(111)$ in the $\mathrm{Cu} \mathrm{LMM}$ Auger spectra (Fig. S1c-e). This suggests that $\mathrm{CeO}_{2}(110)$ has a more remarkable capability to stabilize $\mathrm{Cu}^{+}$compared to $\mathrm{CeO}_{2}(100)$ and $\mathrm{CeO}_{2}(111)$. Fig. $1 \mathrm{c}$ shows the $\mathrm{Ce} 3 d$ signals of

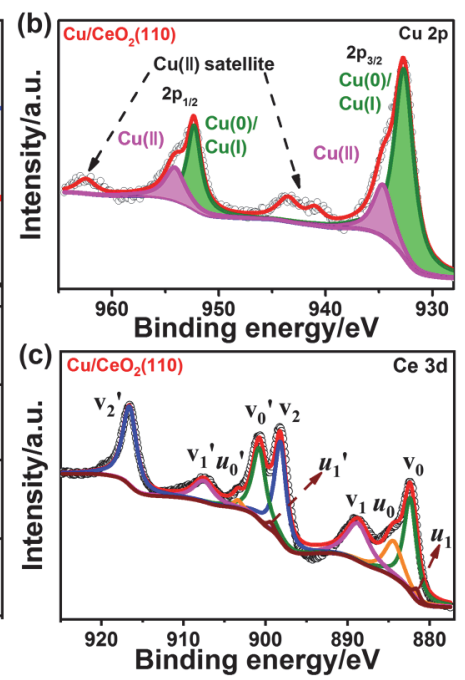

Fig. 1 (a) XRD patterns of $\mathrm{Cu} / \mathrm{CeO}_{2}(111), \mathrm{Cu} / \mathrm{CeO}_{2}(110)$, and $\mathrm{Cu} / \mathrm{CeO}_{2}(100)$; (b) $\mathrm{Cu} 2 p$ and (c) $\mathrm{Ce} 3 d \mathrm{XPS}$ spectra of $\mathrm{Cu} / \mathrm{CeO}_{2}(110)$. 
$\mathrm{Cu} / \mathrm{CeO}_{2}$ (110), which display a satellite structure arising from hybridization of Ce $3 d$ orbitals with $\mathrm{O} 2 p$ orbitals and partial occupation of the $4 f$ levels. The $3 d_{5 / 2}$ and $3 d_{3 / 2}$ spin-orbit peaks (spin-orbit splitting, about $18.5 \mathrm{eV}$ ) are depicted as $v$ and $v^{\prime}$, respectively, attributed to $\mathrm{Ce}^{4+}$. The peaks of $v_{0}$ and $v_{1}$ were assigned to a mixing configuration of the $3 d^{9} 4 f^{2}\left(\mathrm{O} 2 p^{4}\right)$ and $3 d^{9}$ $4 f^{1}\left(\mathrm{O} 2 p^{5}\right) \mathrm{Ce}^{4+}$ states and $v_{2}$ to the $3 d^{9} 4 f^{0}\left(\mathrm{O} 2 p^{6}\right) \mathrm{Ce}^{4+}$ state. A similar assignment was used to analyze the $v^{\prime}$ structures, in accordance with the $\mathrm{Ce} 3 d_{3 / 2}$ level. This manifests the predominated state of $\mathrm{Ce}^{4+}$ in the samples, matching with the XRD results. Four peaks $u_{0}(\mathrm{BE} \approx 884.5 \mathrm{eV}), u_{1}(\mathrm{BE} \approx 881.6$ $\mathrm{eV}), u_{0}{ }^{\prime}(\mathrm{BE} \approx 903.4 \mathrm{eV})$, and $u_{1}{ }^{\prime}(\mathrm{BE} \approx 899.5 \mathrm{eV})$ corresponding to $\mathrm{Ce}^{3+}$ could be observed, suggesting the formation of $\mathrm{Ce}_{2} \mathrm{O}_{3}$ in the samples ${ }^{40}$. Fig. S1f displays $\mathrm{N}_{2}$ adsorption-desorption isotherms of the $\mathrm{Cu} / \mathrm{CeO}_{2}$ samples. A typical type I-isotherm can be observed according to the BDDT (Brunauer, Deming, Deming, and Teller) classification ${ }^{41}$. The BET (BrunauerEmmett-Teller) surface area is $90.1,46.3$, and $101.1 \mathrm{~m}^{2} \cdot \mathrm{g}^{-1}$ for $\mathrm{Cu} / \mathrm{CeO}_{2}$ (111), $\mathrm{Cu} / \mathrm{CeO}_{2}(100)$, and $\mathrm{Cu} / \mathrm{CeO}_{2}(110)$, respectively.

The morphological features of the resulting $\mathrm{CeO}_{2}$ nanocrystals and $\mathrm{Cu} / \mathrm{CeO}_{2}$ samples were examined by TEM and HAADFSTEM. As revealed by TEM (Fig. 2), well-defined $\mathrm{CeO}_{2}$ samples with a morphology of cubes, rods, and octahedra were formed. The as-synthesized $\mathrm{CeO}_{2}$ has good crystallinity. Predominant $\mathrm{CeO}_{2}\{100\}$ and $\{200\}$ planes were observed, as confirmed by their lattice spacing ${ }^{36}$, with the $\mathrm{CeO}_{2}$ cubes exhibiting an average size of about $18.0 \mathrm{~nm}$ (Fig. 2a,b). Whereas
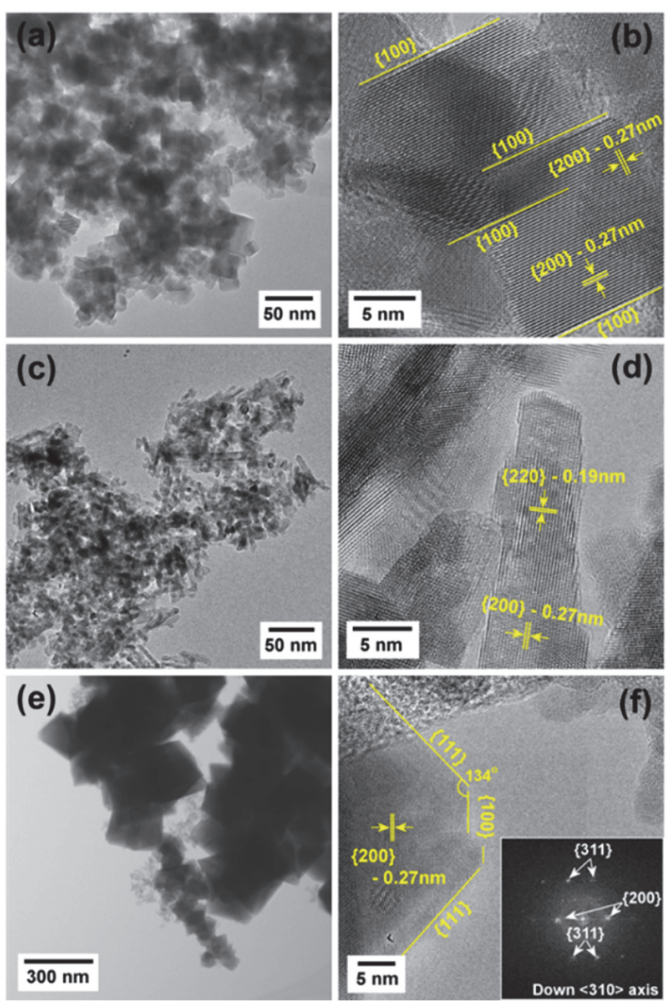

Fig. 2 TEM and HRTEM images of $\mathrm{CeO}_{2}$ with different shapes: $(a, b)$ cubes; $(c, d)$ rods; and $(e, f)$ octahedra. The inset in image (f) illustrates the corresponding FFT.
$\{220\}$ planes with a $d$-spacing of $0.19 \mathrm{~nm}^{37}$ were identified for $\mathrm{CeO}_{2}$ rods with a mean diameter and length of about 6.7 and 27.6 nm, respectively (Fig. 2c,d). By fast Fourier transformation (FFT) (inset of Fig. 2f), the exposed facet of $\{111\}{ }^{36}$ was indexed for a $\mathrm{CeO}_{2}$ octahedra (Fig. 2e,f), with a size of $\sim 180.0$ $\mathrm{nm}$. Fig. $3 \mathrm{a}-\mathrm{f}$ shows the STEM images and electron energy loss spectroscopy (EELS) spectra of $\mathrm{Cu} / \mathrm{CeO}_{2}(100), \mathrm{Cu} / \mathrm{CeO}_{2}(110)$, and $\mathrm{Cu} / \mathrm{CeO}_{2}(111)$. It can be seen that the morphology of respective $\mathrm{CeO}_{2}$ retained regardless of $\mathrm{Cu}$ decoration (Fig. $3 \mathrm{a}, \mathrm{c}, \mathrm{e})$. The EEL spectra at Ce $M_{5,4}$ edges matched what we expected for $\mathrm{CeO}_{2}$ (Fig. 3b,d,f) ${ }^{42}$. The EEL spectra at the $\mathrm{Cu} L_{2,3}$ edges manifested adsorption jumps at $E\left(L_{3}\right)$ of about $930 \mathrm{eV}$ and $E\left(L_{2}\right)$ of about $950 \mathrm{eV}$, corresponding to transitions from $2 p$ core levels to unoccupied $3 d$ levels present in oxidized $\mathrm{Cu}$. Based on HRTEM and FFT, $f c c \mathrm{CuO}$ NPs of about $5 \mathrm{~nm}$ surrounded by $\mathrm{CeO}_{2}$ nanocrystals were discerned (Fig. $3 \mathrm{~g}-\mathrm{i}$ ). The formation of $\mathrm{CuO}$ is likely due to oxidation of metallic $\mathrm{Cu}$ after exposure of the samples in the air.

\subsection{Investigation of $\mathrm{Cu} / \mathrm{CeO}_{2}$ for electrochemical $\mathrm{CO}_{2}$ reduction}

The catalytic properties of $\mathrm{Cu} / \mathrm{CeO}_{2}$ catalysts toward $\mathrm{CO}_{2}$ reduction were tested in $\mathrm{CO}_{2}$-saturated $0.1 \mathrm{~mol} \cdot \mathrm{L}^{-1} \mathrm{KHCO}_{3}$ solutions ( $\mathrm{pH}$ 6.8) using an H-type cell under continuous $\mathrm{CO}_{2}$ bubbling. The geometric current densities of $\mathrm{Cu} / \mathrm{CeO}_{2}$ samples were examined by linear sweep voltammetry (LSV) with applied voltages in the range from 0.00 to $-1.40 \mathrm{~V}$, as displayed in Figs. 4a and $\mathrm{S} 2 \mathrm{a}$. Of note, for all three $\mathrm{Cu} / \mathrm{CeO}_{2}$ samples remarkably higher cathodic current densities were attained in a $\mathrm{CO}_{2}$ environment compared with an Ar atmosphere throughout the
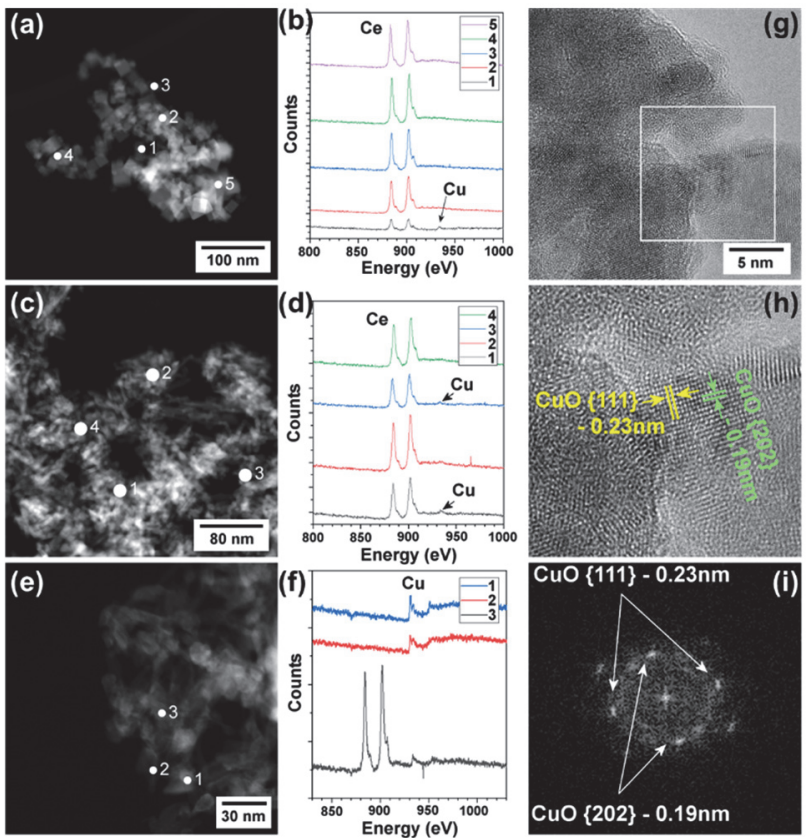

Fig. 3 STEM images and EELS spectra of (a, b) $\mathrm{Cu} / \mathrm{CeO}_{2}(100)$, (c, d) $\mathrm{Cu} / \mathrm{CeO}_{2}(110)$, (e, f) $\mathrm{Cu} / \mathrm{CeO}_{2}(111)$; (g) HRTEM image of $\mathrm{Cu} / \mathrm{CeO}_{2}$ (111); (h) enlarged image of the white rectangle in image (g); (i) FFT of the region shown in image (h). 

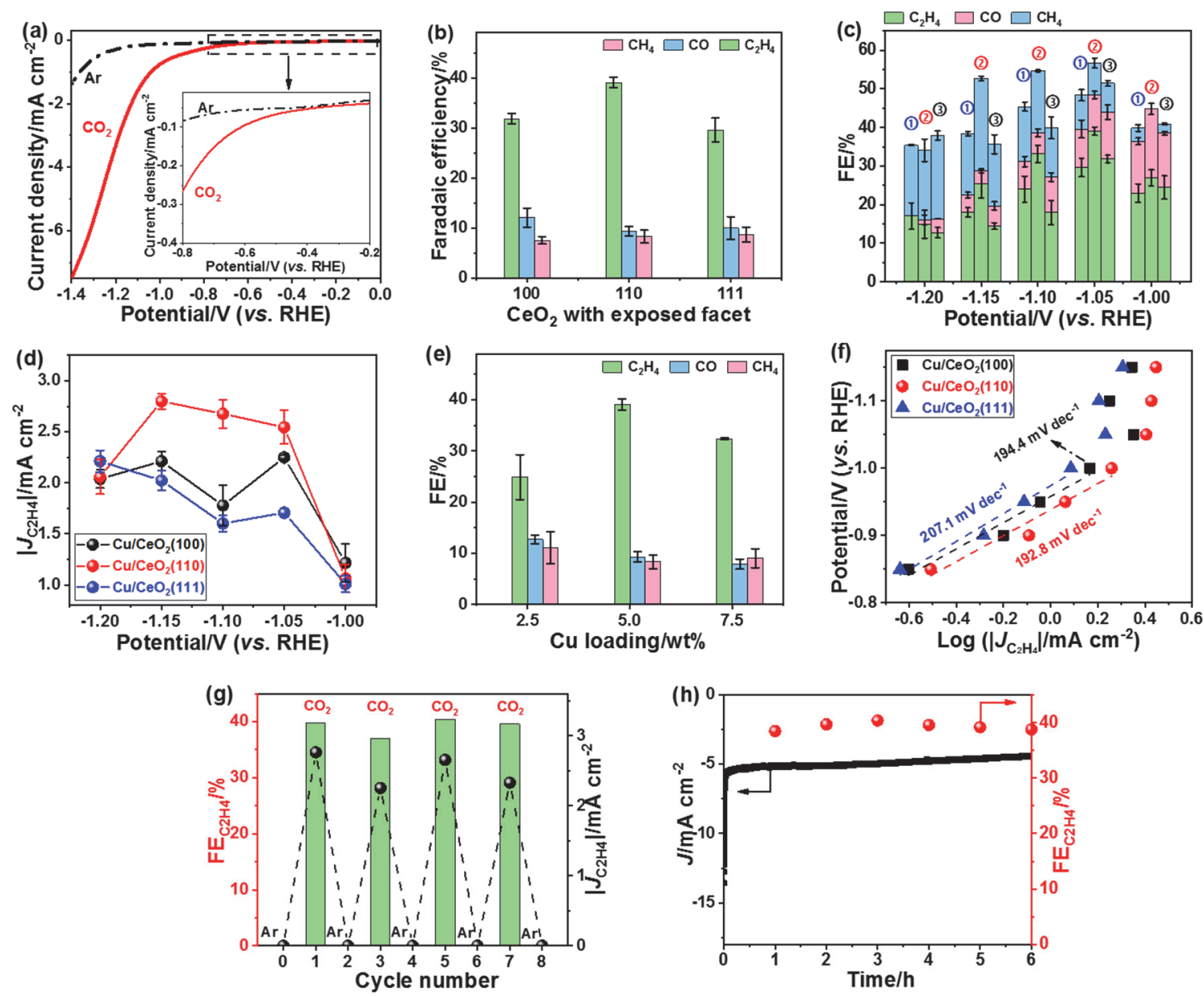

Fig. 4 (a) $\mathrm{LSV}$ results of $\mathrm{Cu} / \mathrm{CeO}_{2}(110)$ on a glassy carbon electrode in $\mathrm{Ar}$ - (dashed black line) or $\mathrm{CO}_{2}$ (solid red line)-saturated $0.1 \mathrm{~mol} \cdot \mathrm{L}^{-1}$ $\mathrm{KHCO}_{3}$ at a scan rate of $5 \mathrm{mV} \cdot \mathrm{s}^{-1}$. (b) Faradaic efficiencies for $\mathrm{ECR}$ products of $\mathrm{Cu} / \mathrm{CeO}_{2}(100), \mathrm{Cu} / \mathrm{CeO}_{2}(110)$, and $\mathrm{Cu} / \mathrm{CeO}_{2}(111)$ at $-1.05 \mathrm{~V}$. (c) Overall ECR Faradaic efficiencies and (d) $\mathrm{C}_{2} \mathrm{H}_{4}$ geometric current densities over $\mathrm{Cu} / \mathrm{CeO}_{2}(111)$ (named as (1)), $\mathrm{Cu} / \mathrm{CeO}_{2}(110)$ (named as (2)), and $\mathrm{Cu} / \mathrm{CeO}_{2}(100)$ (named as (3) at various applied potentials. (e) ECR Faradaic efficiencies at $-1.05 \mathrm{~V}$ as a function of $\mathrm{Cu}$ loading over $\mathrm{Cu} / \mathrm{CeO}_{2}(110)$.

(f) Tafel plots of the partial geometric current density for $\mathrm{C}_{2} \mathrm{H}_{4}$ production over $\mathrm{Cu} / \mathrm{CeO}_{2}(100), \mathrm{Cu}_{/} \mathrm{CeO}_{2}(110)$, and $\mathrm{Cu} / \mathrm{CeO}_{2}(111)$. (g) $\mathrm{C}_{2} \mathrm{H}_{4} \mathrm{FEs}$

(column) and corresponding partial geometric current densities (ball) for $\mathrm{Cu} / \mathrm{CeO}_{2}(110)$ during cycles with an interval of $1 \mathrm{~h}$ in $\mathrm{CO}_{2}$-and Ar-saturated $0.1 \mathrm{~mol} \cdot \mathrm{L}^{-1} \mathrm{KHCO}_{3}$. (h) Current density and $\mathrm{C}_{2} \mathrm{H}_{4} \mathrm{FE}$ of $\mathrm{Cu} / \mathrm{CeO}_{2}(110)$ during long-time electrolysis at $-1.05 \mathrm{~V}$.

potential range applied. $\mathrm{CO}, \mathrm{H}_{2}, \mathrm{CH}_{4}, \mathrm{C}_{2} \mathrm{H}_{4}$ were probed at working voltages from -1.00 to $-1.20 \mathrm{~V}$ in a $\mathrm{CO}_{2}$-saturated 0.1 $\mathrm{mol} \cdot \mathrm{L}^{-1} \mathrm{KHCO}_{3}$ solution. In sharp contrast, pure carbon paper, $\mathrm{CeO}_{2}(100), \mathrm{CeO}_{2}(110)$, and $\mathrm{CeO}_{2}(111)$ exclusively produced $\mathrm{H}_{2}$ within the applied potentials (Fig. S2b-e), indicating their poor activities for ECR. At $-1.05 \mathrm{~V}$, the ECR took place over HER for all the three $\mathrm{Cu} / \mathrm{CeO}_{2}$ samples. The overall ECR FE over $\mathrm{Cu} / \mathrm{CeO}_{2}(110) \quad(\mathrm{FE} \approx 56.7 \%)$ outperformed that of both $\mathrm{Cu} / \mathrm{CeO}_{2}(100)(\mathrm{FE} \approx 51.5 \%)$ and $\mathrm{Cu} / \mathrm{CeO}_{2}(111)(\mathrm{FE} \approx 48.4 \%)$ (Fig. 4b,c). Strikingly, $\mathrm{Cu} / \mathrm{CeO}_{2}(110)$ exhibited the highest selectivity for $\mathrm{C}_{2} \mathrm{H}_{4}$ formation $\left(\mathrm{FEC}_{2} \mathrm{H}_{4} \approx 39.1 \%\right.$ ) at $-1.05 \mathrm{~V}$ compared to $\mathrm{Cu} / \mathrm{CeO}_{2}(100)\left(\mathrm{FE}_{\mathrm{C}_{2} \mathrm{H}_{4}} \approx 31.8 \%\right)$ and $\mathrm{Cu} / \mathrm{CeO}_{2}(111)$ $\left(\mathrm{FE}_{\mathrm{C}_{2} \mathrm{H}_{4}} \approx 29.6 \%\right.$ ). The $\mathrm{C}_{2} \mathrm{H}_{4}$ selectivity is comparable to many reported $\mathrm{Cu}$-based materials under similar overpotentials such as $\mathrm{Cu}$ nanocubes with exposed (100) facets $\left(\mathrm{FE}_{\mathrm{C}_{2} \mathrm{H}_{4}} \approx 32.0 \%\right){ }^{43}$, $\mathrm{Ag}-\mathrm{Cu}$ nanodimers $\left(\mathrm{FE}_{\mathrm{C}_{2} \mathrm{H}_{4}} \approx 40.0 \%\right){ }^{44}$, and carbon electrocatalysts such as $\mathrm{N}$-doped graphene quantum dots $\left(\mathrm{FE}_{2} \mathrm{H}_{4}\right.$ $\leq 31.0 \%)^{45}$. Likewise, $\mathrm{Cu} / \mathrm{CeO}_{2}(110)$ also displayed significantly larger $\mathrm{C}_{2} \mathrm{H}_{4}$ partial geometric current density than the other two catalysts (Fig. 4d). Comparably lower CO generation was observed for $\mathrm{Cu} / \mathrm{CeO}_{2}(110)$ attributed to its higher hydrocarbon production, which consumed the $\mathrm{CO}$ intermediate. The high intrinsic activity of the $\mathrm{Cu} / \mathrm{CeO}_{2}(110)$ sample may be closely correlated to the nature of the metastable (110) surface ${ }^{46}$. On the one hand, $\mathrm{CeO}_{2}$ facilitated effective adsorption of $\mathrm{CO}_{2}$, forming carbonates and hydrogen carbonates, thereby benefiting ECR ${ }^{35}$. On the other hand, $\mathrm{CeO}_{2}(110)$ could significantly stabilize $\mathrm{Cu}^{+}$, which was believed to play a critical role in the ECR to produce $\mathrm{C}_{2} \mathrm{H}_{4}{ }^{35}$. The ceria nanocrystals with different facets synthesized here were all larger than $5 \mathrm{~nm}$, therefore, the size of ceria was unlikely to affect the catalytic performance ${ }^{47}$. These point to the possibility that the exposed $\mathrm{CeO}_{2}$ (110) facets favored ECR over $\mathrm{Cu}$ selectively to $\mathrm{C}_{2} \mathrm{H}_{4}$.

At applied overpotentials more positive than $-1.05 \mathrm{~V}$, more $\mathrm{CO}$ than $\mathrm{CH}_{4}$ was produced while $\mathrm{CH}_{4}$ dominated in the ECR products at more negative potentials than $-1.15 \mathrm{~V}$ for the three 
catalysts. At voltages $\leq-1.20 \mathrm{~V}$, the FE of evolved $\mathrm{H}_{2}$ surpassed $50.0 \%$, which tended to increase with increasing overpotential. This is most probably due to restricted $\mathrm{CO}_{2}$ mass transport and thus more protons available for facile occurrence of the competing HER. Moreover, the effect of $\mathrm{Cu}$ loading in $\mathrm{Cu} / \mathrm{CeO}_{2}$ (110) on ECR was investigated (Fig. 4e). It was found that the ECR FE increased with improving the content of $\mathrm{Cu}$ from $2.5 \%(w)$ to $5.0 \%(w)$. This may be due to the increase of the interface between $\mathrm{Cu}$ and $\mathrm{CeO}_{2}$. However, further increase in $\mathrm{Cu}$ loading from $5.0 \%(w)$ to $7.5 \%(w)$ resulted in drop of ECR performance, which was probably attributed to aggregation of $\mathrm{Cu}$ NPs and thus decrease of the interfacial area of $\mathrm{Cu}$ with $\mathrm{CeO}_{2}$.

The reaction kinetics were studied by Tafel analysis. A Tafel slope of $192.8 \mathrm{mV} \cdot \mathrm{dec}^{-1}$ was derived for $\mathrm{Cu} / \mathrm{CeO}_{2}(110)$, smaller than $194.4 \mathrm{mV} \cdot \mathrm{dec}^{-1}$ for $\mathrm{Cu} / \mathrm{CeO}_{2}(100)$ and $207.1 \mathrm{mV} \cdot \mathrm{dec}^{-1}$ for $\mathrm{Cu} / \mathrm{CeO}_{2}$ (111) (Fig. 4f). This indicates that the $\mathrm{Cu} / \mathrm{CeO}_{2}(110)$ has a faster kinetics for ECR to generate $\mathrm{C}_{2} \mathrm{H}_{4}$. The generation of the *CO intermediate for subsequent reactions on the surface of the catalysts may be the rate-controlling process. The Nyquist plots showed a lower charge transfer resistance of $\mathrm{Cu} / \mathrm{CeO}_{2}(110)$ NPs than both $\mathrm{Cu} / \mathrm{CeO}_{2}(100)$ and $\mathrm{Cu} / \mathrm{CeO}_{2}$ (111) (Fig. S2f), indicating its more favorable electron exchange between the catalyst on the electrode surface and dissolved $\mathrm{CO}_{2}$ in the electrolyte, benefiting ECR.

The stability of the ECR process over $\mathrm{Cu} / \mathrm{CeO}_{2}(110)$ was evaluated by alternated electrolysis between $\mathrm{Ar}-$ and $\mathrm{CO}_{2}$ saturated electrolytes (Fig. 4g) as well as continuous electrolysis under $\mathrm{CO}_{2}$ environment at a fixed potential of $-1.05 \mathrm{~V}$ for $6 \mathrm{~h}$ (Fig. 4h). It is worth noting that the catalyst remained steady for $\mathrm{C}_{2} \mathrm{H}_{4}$ formation in both cases.

\section{Conclusions}

To be concluded, we have demonstrated facile synthesis of $\mathrm{Cu}$ NPs supported on $\mathrm{CeO}_{2}$ nanocrystals (cubes, rods, and octahedra) with different exposed facets. The $\mathrm{Cu} / \mathrm{CeO}_{2}$ nanocomposites were observed to exhibit facet dependent catalytic properties for ECR in $0.1 \mathrm{~mol} \cdot \mathrm{L}^{-1} \mathrm{KHCO}_{3}$ solutions at ambient conditions. The $\mathrm{Cu} / \mathrm{CeO}_{2}(110)$ catalyst delivered higher ECR performance than both $\mathrm{Cu} / \mathrm{CeO}_{2}(100)$ and $\mathrm{Cu} / \mathrm{CeO}_{2}(111)$ in terms of ECR FE and partial geometric current density. Especially, the $\mathrm{FE}_{\mathrm{C} 2 \mathrm{H} 4}$ and $J_{\mathrm{C} 2 \mathrm{H} 4}$ over $\mathrm{Cu} / \mathrm{CeO}_{2}(110)$ reached up to $39.1 \%$ and $2.5 \mathrm{~mA} \cdot \mathrm{cm}^{-2}$ at $-1.05 \mathrm{~V}$, respectively, in contrast to $31.8 \%$ and $2.2 \mathrm{~mA} \cdot \mathrm{cm}^{-2}$ for $\mathrm{Cu} / \mathrm{CeO}_{2}(100), 29.6 \%$ and 1.7 $\mathrm{mA} \cdot \mathrm{cm}^{-2}$ for $\mathrm{Cu} / \mathrm{CeO}_{2}(111)$. The superior ECR activity of $\mathrm{Cu} / \mathrm{CeO}_{2}(110)$ could be attributed to a strong synergy between $\mathrm{Cu}$ NPs and $\mathrm{CeO}_{2}(110)$ facets, which resulted in more stabilized $\mathrm{Cu}^{1+}$ species, thus promoting $\mathrm{C}-\mathrm{C}$ coupling, formation and desorption of $\mathrm{C}_{2} \mathrm{H}_{4}$. Our work provides a simple and effective avenue for enhancing the ECR toward $\mathrm{C}_{2} \mathrm{H}_{4}$ formation by crystal facet engineering.

Supporting Information: available free of charge via the internet at http://www.whxb.pku.edu.cn.

\section{References}

(1) de Arquer, F. P. G.; Dinh, C. -T.; Ozden, A.; Wicks, J.; McCallum, C.; Kirmani, A. R.; Nam, D. -H.; Gabardo, C.; Seifitokaldani, A.; Wang, X. Science 2020, 367, 661. doi: 10.1126/science.aay4217

(2) Gao, Y. N.; Liu, S. Z.; Zhao, Z. Q.; Tao, H. C.; Sun, Z. Y. Acta Phys. -Chim. Sin. 2018, 34, 858. [高云楠, 刘世桢, 赵振清, 陶亨聪, 孙振宇. 物理化学学报, 2018, 34, 858.] doi: 10.3866/PKU.WHXB201802061

(3) Sun, Z. Y.; Talreja, N.; Tao, H. C.; Texter, J.; Muhler, M.; Strunk, J.; Chen, J. F. Angew. Chem. Int. Ed. 2018, 57, 7610. doi: 10.1002/anie.201710509

(4) Sun, Z. Y.; Ma, T.; Tao, H. C.; Fan, Q.; Han, B. X. Chem 2017, 3, 560. doi: 10.1016/j.chempr.2017.09.009

(5) Ma, T.; Fan, Q.; Tao, H. C.; Han, Z. S.; Jia, M. W.; Gao, Y. N.; Ma, W. J.; Sun, Z. Y. Nanotechnology 2017, 28, 472001. doi: 10.1088/1361-6528/aa8f6f

(6) Yang, Y.; Zhang, Y.; Hu, J. S.; Wan, L. J. Acta Phys. -Chim. Sin. 2020, 36, 1906085. [杨艳, 张云, 胡劲松, 万立骏. 物理化学学报, 2020, 36, 1906085.] doi: 10.3866/PKU.WHXB201906085

(7) Yang, P. P.; Zhang, X. L.; Gao, F. Y.; Zheng, Y. R.; Niu, Z. Z.; Yu, X. X.; Liu, R.; Wu, Z. Z.; Qin, S.; Chi, L. P. J. Am. Chem. Soc. 2020, 142, 6400. doi: 10.1021/jacs.0c01699

(8) Liu, Z. M. Acta Phys. -Chim. Sin. 2019, 35, 1307. [刘志敏. 物理化 学学报, 2019, 35, 1307.] doi: 10.3866/PKU.WHXB201908014

(9) Meng, Y. C.; Kuang, S. Y.; Liu, H.; Fan, Q.; Ma, X. B.; Zhang, S. Acta Phys. -Chim. Sin. 2021, 37, 2006034. [孟怡辰, 况思宇, 刘海, 范群, 马新宾, 张生. 物理化学学报, 2021, 37, 2006034.] doi: 10.3866/PKU.WHXB202006034

(10) Ning, H.; Wang, W. H.; Mao, Q. H.; Zheng, S. R.; Yang, Z. X.; Zhao, Q. S.; Wu, M. B. Acta Phys. -Chim. Sin. 2018, 34, 938. [宁会, 王文 行, 毛勤虎, 郑诗瑞, 杨中学, 赵青山, 吴明铂. 物理化学学报, 2018, 34, 938.] doi: 10.3866/PKU.WHXB201801263

(11) Jia, M. W.; Fan, Q.; Liu, S. Z.; Qiu, J. S.; Sun, Z. Y. Curr. Opin. Green Sustainable Chem. 2019, 16, 1. doi: 10.1016/j.cogsc.2018.11.002

(12) Kim, D.; Kley, C. S.; Li, Y. F.; Yang, P. D. Proc. Natl Acd. Sci. 2017, 114, 10560. doi: 10.1073/pnas.1711493114

(13) Ma, T.; Fan, Q.; Li, X.; Qiu, J. S.; Wu, T. B.; Sun, Z. Y. J. CO Util. 2019, 30, 168. doi: 10.1016/j.jcou.2019.02.001

(14) Jia, M. W.; Hong, S.; Wu, T. B.; Li, X.; Soo, Y. L.; Sun, Z. Y. Chem. Commun. 2019, 55, 12024. doi: 10.1039/C9CC06178A

(15) Tao, H. C.; Sun, X. F.; Back, S.; Han, Z. S.; Zhu, Q. G.; Robertson, A. W.; Ma, T.; Fan, Q.; Han, B. X.; Jung, Y. S.; et al. Chem. Sci. 2018, 9, 483. doi: 10.1039/c7sc03018e 
(16) Jia, M. W.; Choi, C.; Wu, T. S.; Ma, C.; Kang, P.; Tao, H. C.; Fan, Q.; Hong, S.; Liu, S. Z.; Soo, Y. L.; et al. Chem. Sci. 2018, 9, 8775. doi: $10.1039 / \mathrm{C} 8 \mathrm{SC} 03732 \mathrm{~A}$

(17) Fan, Q.; Hou, P. F.; Choi, C.; Wu, T. S.; Hong, S.; Li, F.; Soo, Y. L.; Kang, P.; Jung, Y. S.; Sun, Z. Y. Adv. Energy Mater. 2020, 10, 1903068. doi: 10.1002/aenm.201903068

(18) Li, F.; Gu, G. H.; Choi, C.; Kolla, P.; Sun, Z. Y. Appl. Catal. B Environ. 2020, 277, 119241. doi: 10.1016/j.apcatb.2020.119241

(19) Fan, Q.; Zhang, M. L.; Jia, M. W.; Liu, S. Z.; Qiu, J. S.; Sun, Z. Y. Mater. Today Energy 2018, 10, 280. doi: 10.1016/j.mtener.2018.10.003

(20) Lee, S. Y.; Jung, H.; Kim, N. K.; Oh, H. S.; Min, B. K.; Hwang, Y. J. J. Am. Chem. Soc. 2018, 140, 8681. doi: 10.1021/jacs.8b02173

(21) Huang, J.; Mensi, M.; Oveisi, E.; Mantella, V.; Buonsanti, R. J. Am. Chem. Soc. 2019, 141, 2490. doi: 10.1021/jacs.8b12381

(22) Loiudice, A.; Lobaccaro, P.; Kamali, E. A.; Thao, T.; Huang, B. H.; Ager, J. W.; Buonsanti, R. Angew. Chem. Int. Ed. 2016, 55, 5789. doi: 10.1002/anie.201601582

(23) Ren, D.; Deng, Y. L.; Handoko, A. D.; Chen, C. S.; Malkhandi, S.; Yeo, B. S. ACS Catal. 2015, 5, 2814. doi: 10.1021/cs502128q

(24) Li, Y. M.; Chu, S. L.; Shen, H. D.; Xia, Q. N.; Robertson, A. W.; Masa, J.; Siddiqui, U.; Sun, Z. Y. ACS Sustainable Chem. Eng. 2020, 8, 4948. doi: 10.1021/acssuschemeng.0c00800

(25) Han, Z. S.; Choi, C.; Tao, H. C.; Fan, Q.; Gao, Y. N.; Liu, S. Z.; Robertson, A. W.; Hong, S.; Jung, Y. S.; Sun, Z. Y. Catal. Sci. Technol. 2018, 8, 3894. doi: 10.1039/C8CY01037D

(26) Chu, S. L.; Hong, S.; Masa, J.; Li, X.; Sun, Z. Y. Chem. Commun. 2019, 55, 12380. doi: 10.1039/C9CC05435A

(27) Kašpar, J.; Fornasiero, P.; Graziani, M. Catal. Today 1999, 50, 285. doi: 10.1016/S0920-5861(98)00510-0

(28) Carrettin, S.; Concepción, P.; Corma, A.; Nieto, J. M. L.; Puntes, V. F. Angew. Chem. Int. Ed. 2004, 43, 2538. doi: $10.1002 /$ anie. 200353570

(29) Campbell, C. T.; Peden, C. H. Science 2005, 309, 713. doi: 10.1126/science. 1113955

(30) Trovarelli, A. Comments Inorg. Chem. 1999, 20, 263. doi: $10.1080 / 02603599908021446$

(31) Trovarelli, A.; Llorca, J. ACS Catal. 2017, 7, 4716. doi: $10.1021 /$ acscatal. $7 \mathrm{~b} 01246$

(32) Xu, J. H.; Harmer, J.; Li, G. Q.; Chapman, T.; Collier, P.; Longworth,
S.; Tsang, S. C. Chem. Commun. 2010, 46, 1887 doi: 10.1039/b923780a

(33) Mai, H. X.; Sun, L. D.; Zhang, Y. W.; Si, R.; Feng, W.; Zhang, H. P.; Liu, H. C.; Yan, C. H. J. Phys. Chem. B 2005, 109, 24380. doi: $10.1021 / \mathrm{jp} 055584 \mathrm{~b}$

(34) Ye, L.; Mahadi, A. H.; Saengruengrit, C.; Qu, J.; Xu, F.; Fairclough, S. M.; Young, N.; Ho, P. L.; Shan, J. J.; Nguyen, L. ACS Catal. 2019, 9, 5171. doi: 10.1021/acscatal.9b00421

(35) Chu, S. L.; Yan, X. P.; Choi, C.; Hong, S.; Robertson, A. W.; Masa, J.; Han, B. X.; Jung, Y. S.; Sun, Z. Y. Green Chem. 2020, 22, 6540. doi: 10.1039/D0GC02279A

(36) Ha, H.; Yoon, S.; An, K.; Kim, H. Y. ACS Catal. 2018, 8, 11491. doi: 10.1021/acscatal.8b03539

(37) Li, C. W.; Sun, Y.; Djerdj, I.; VPel, P.; Sack, C. C.; Weller, T.; Sann, J.; Ellinghaus, R.; Guo, Y. L.; Smarsly, B. M. ACS Catal. 2017, 7, 6453. doi: 10.1021/acscatal.7b01618

(38) Désaunay, T.; Bonura, G.; Chiodo, V.; Freni, S.; Couzinié, J. -P.; Bourgon, J.; Ringuedé, A.; Labat, F.; Adamo, C.; Cassir, M. J. Catal. 2013, 297, 193. doi: 10.1016/j.jcat.2012.10.011

(39) Platzman, I.; Brener, R.; Haick, H.; Tannenbaum, R. J. Phys. Chem. C 2008, 112, 1101. doi: 10.1021/jp076981k

(40) Sun, Z. Y.; Wang, X.; Liu, Z. M.; Zhang, H. Y.; Yu, P.; Mao, L. Q. Langmuir 2010, 26, 12383. doi: 10.1021/la101060s

(41) Haul, R. Acad. Press 1982, 86, 957. doi: 10.1002/bbpc. 19820861019

(42) Garvie, L. A. J.; Buseck, P. R. J. Phys. Chem. Solids 1999, 60, 1943. doi: 10.1016/S0022-3697(99)00218-8

(43) Jiang, K.; Sandberg, R. B.; Akey, A. J.; Liu, X. Y.; Bell, D. C.; Nørskov, J. K.; Chan, K.; Wang, H. Nat. Catal. 2018, 1, 111. doi: 10.1038/s41929-017-0009-х

(44) Huang, J. F.; Mensi, M.; Oveisi, E.; Mantella, V.; Buonsanti, R. J. Am. Chem. Soc. 2019, 141, 2490. doi: 10.1021/jacs.8b12381

(45) Wu, J.; Ma, S.; Sun, J.; Gold, J. I..; Tiwary, C.; Kim, B.; Zhu, L.; Chopra, N.; Odeh, I. N.; Vajtai, R.; et al. Nat. Commun. 2016, 7, 13869. doi: $10.1038 /$ ncomms 13869

(46) Kumari, N.; Haider, M. A.; Agarwal, M.; Sinha, N.; Basu, S. J. Phys. Chem. C 2016, 120, 16626. doi: 10.1021/acs.jpcc.6b02860

(47) Ye, L.; Mahadi, A. H.; Saengruengrit, C.; Qu, J.; Xu, F.; Fairclough, S. M.; Young, N.; Ho, P. -L.; Shan, J.; Nguyen, L. ACS Catal. 2019, 9, 5171. doi: 10.1021/acscatal.9b00421 